\author{
Н.В. Онучина, А.В. Кузнецовский, В.Д. Сойбанов \\ Филиал федерального государственного бюджетного учреждения \\ "48 Центральный научно-исследовательский институт» \\ Министерства обороны Российской Федерации, 610000, \\ Российская Федерация, г. Киров, Октябрьский проспект, д. 119
}

\begin{abstract}
Поступила 20.11.2018 г. Принята к публикации 10.03.2019 г.
Возбудитель сибирской язвы - Bacillus anthracis, вследствие распространенности его природных очагов на территории России, высокой вирулентности для человека и большинства млекопитающих, уникальной устойчивости споровых форм к воздействию факторов окружающей среды и неоднократного применения в террористических актах, представляет собой крайне опасный биологический агент. Поэтому необходим поиск новых эффективных препаратов для диагностики и лечения сибирской язвы, в том числе и заболеваний, вызванных антибиотико-устойчивыми штаммами B. anthracis. Новым направлением в диагностике, профилактике и лечении инфекционных заболеваний является использование литических ферментов видоспецифических бактериофагов. Цель работы - клонирование гена сибиреязвенного бактериолизина $\mathrm{PlyPH}$ в составе вектора p TrcHis2C в Escherichia coli и исследование in vitro литических свойств кодируемого им белка в отношении микробных клеток B. anthracis. По данным полного секвенирования геномов B. anthracis штаммов Ames, Stern 34F2 и JB17 был выявлен в составе их хромосомной ДНК профаг, утративший часть структурных генов, необходимых для его репликации, но сохранивший ген, имеющий высокую степенью гомологии с геном бактериолизина $\gamma$ фага. Для амплификации и последующего клонирования гена $P l y P H$ нами были разработаны праймеры, содержащие сайты узнавания рестриктаз EcoRI и BamHI. Амплификацию гена $P l y \mathrm{PH}$ в полимеразной цепной реакции (ПЦР) с разработанной парой праймеров проводили, используя в качестве матрицы ДНК штамма Stern 34F2 сибиреязвенного микроба. На основе полученных продуктов амплификации и вектора pTrcHis2C нами сконструирована рекомбинантная плазмида, содержащая ген $\mathrm{Ply} P \mathrm{PH}$ синтеза бактериолизина и стабильно функционирующая в клетках рекомбинантного штамма E. coli. В ходе исследований установлено, что микробные клетки рекомбинантного штамма ТОР10 E. coli обеспечивают продукцию бактериолизина сибиреязвенного профага - PlyPH, обладающего способностью in vitro лизировать вегетативные клетки вакцинного штамма B. anthracis CТИ-1.
\end{abstract}

Ключевые слова: Bacillus anthracis; вектор pTrcHis2C; клонирование; сибиреязвенный бактериолизин РlyРН; сибиреязвенный профаг; сибирская язва.

Библиографическое описание: Онучина Н.В., Кузнеиовский А.В., Сойбанов В.Д. Оиенка возможности получения рекомбинантного белка сибиреязвенного бактериолизина PlyPH и исследование in vitro его литических свойств в отношении микробных клеток Bacillus anthracis // Вестник войск РХБ защиты. 2019. Т. 3. № 1. С. 15-22.

Сибирская язва - острая инфекционная болезнь группы зооантропонозов, которая характеризуется тяжестью течения и высокой летальностью. Высокая вирулентность возбудителя сибирской язвы для человека и большинства млекопитающих в сочетании с уникальной устойчивостью споровых форм к воздействию факторов окружающей среды 
ставят его в разряд крайне опасных биологических агентов. На территории нашей страны зарегистрировано около 35 тыс. стационарно неблагополучных пунктов, где находятся сибиреязвенные захоронения, которые при отсутствии необходимых санитарно-противоэпидемических (профилактических) мероприятий в любой момент могут стать причиной заболевания человека [1-3]. Кроме того, сохраняется реальная опасность биологического терроризма с применением в качестве поражающего агента возбудителя сибирской язвы [4-6]. Данные обстоятельства обуславливают актуальность исследований по поиску новых эффективных препаратов для диагностики и лечения сибирской язвы, в том числе и заболеваний, вызванных антибиотико-устойчивыми штаммами возбудителя болезни.

Новым направлением в диагностике, профилактике и лечении инфекционных заболеваний является использование литических ферментов видоспецифических бактериофагов. Литические ферменты, отвечающие за лизис микробных клеток бактериальных хозяев, также называют фаг-ассоциированными лизинами или энзимобиотиками. Исследования белковой структуры бактериальных лизинов, кодируемых фагами, показали, что их $\mathrm{N}$-концевой домен обладает ферментативной активностью в отношении пептидогликана, а С-концевой домен определяет специфическое связывание белка с полисахаридными эпитопами клеточной стенки бактерий [7]. Механизм литического действия бактериолизинов схож с действием таких ферментов, как мурамидазы, глюкозаминидазы и эндопептидазы.

Фаг-ассоциированные лизины пневмококкового бактериолизина уже были успешно применены исследователями из института Рокфеллера (США) при лечении экспериментальной токсико-септицемии мышей [8]. Очищенный препарат лизировал клинические штаммы пневмококка, в том числе и устойчивые к пенициллину. Выживание мышей опытной группы при этом составило 100 \%. Позже эта же группа ученых в серии опытов на мышах также продемонстрировала эффективность фаголизина стрептококков группы В [9]. Однако особый интерес представляют исследования американских ученых в отношении фаголизина B. anthracis, полученного с использованием генно-инженерных методов из сибиреязвенного $\gamma$ фага $[10,11]$. Его очищенный препарат показал высокую эффективность in vitro, лизировал за 2 мин более $5 \times 10^{7}$ м.к./мл B. anthracis в 1 мл, а его введение инфицированным животным обеспечило выживание 70 \% белых мышей. По мнению самих авторов, у данного препарата большие перспективы для использования как для диагностики, так и в целях профилактики и лечения сибирской язвы.

Актуальность работы обусловлена необходимостью поиска новых эффективных препаратов для диагностики и лечения сибирской язвы, в том числе и заболеваний, вызванных антибиотико-устойчивыми штаммами B. anthracis. Кроме того, бактериолизины имеют преимущество перед антибактериальными препаратами, поскольку обладают активностью в отношении конкретных возбудителей и оказывают минимальное воздействие на другие микроорганизмы, в том числе комменсалы. Все это делает их пригодными в качестве альтернативных терапевтических агентов.

Цель работы - клонирование гена сибиреязвенного бактериолизина $\mathrm{PlyPH}$ в составе вектора pTrcHis2C в E. coli и исследование in vitro литических свойств кодируемого им белка в отношении микробных клеток B. anthracis.

\section{Материалы и методы}

Штаммы микроорганизмов и плазмиды. В работе использовали вакцинный штамм СТИ-1 B. anthracis и бесплазмидный штамм TOP10 E. coli, дефектный по синтезу протеаз и рестриктаз; коммерческий вектор pTrcHis2C («Invitrogen ${ }^{\mathrm{rm}} »$, США).

Питательные среды и реактивы. Штаммы микроорганизмов выращивали на плотной питательной среде, содержащей сердечно-мозговой экстракт (BHI, «Difco», США), в жидкой питательной среде (LB-бульон, «Amresco», США).

Плазмидную ДНК из рекомбинантных штаммов $E$. coli выделяли с помощью набора реактивов GeneJet ${ }^{\mathrm{t} M}$ Plasmid Miniprep Kit («Fermentas», Литва).

Химический синтез праймеров для клонирования гена PlyPH осуществляли фосфоамидитным методом на автоматическом синтезаторе ACM-102-U (TOО «Биосан», г. Новосибирск). Очистку олигонуклеотидов проводили методом жидкостной хроматографии высокого давления.

Амплификацию ДНК проводили методом ПЦР с синтезированными для клонирования гена $P l y P H$ праймерами в термоциклере MC-2 «Терцик» (ООО «ДНК-Технология», Россия). Температурно-временные режимы полимеразной цепной реакции (ПЦР) подбирали экспериментально.

Продукты амплификации очищали с помощью набора Montage ${ }^{\mathrm{Tm}}$ PCR Centrifugal Filter Devices (фирмы «Millipore», США) в соответствии с рекомендациями производителя.

Реакции рестрикции и лигирования ДНК проводили в соответствии с рекоменда- 
циями фирмы - производителя ферментов (НПО «СибЭнзим», Россия).

Эффект рестрикции/лигирования подтверждали методом электрофореза в 1-1,5\% агарозном геле в сравнении с контрольными препаратами ДНК.

Белковый профиль рекомбинантных клонов штамма TOP10 E. coli анализировали методом электрофореза в полиакриламидном геле (ПААГ). При подготовке образцов к электрофорезу к 1 мл бактериальной суспензии исследуемого клона, содержащей по стандарту мутности ГИСК им. Л.А. Тарасевича 10 млрд. м.к./мл, добавляли 200 мкл раствора (20\% - сахарозы, 12 \% - додецилсульфата натрия, 30 \% 2-меркаптоэтанола и 0,03 \% - бромфенолового синего), тщательно перемешивали пипетированием и прогревали на кипящей водяной бане в течение 5 мин. Для контроля полноты инактивации прогретую суспензию бактерий высевали на плотную питательную среду.

\section{Результаты и обсуждение}

На первом этапе исследований необходимо было определить структурный ген сибиреязвенного бактериолизина, провести анализ его нуклеотидной последовательности и оценить возможности по его клонированию в E. coli. Изучение результатов полного секвенирования геномов $B$. anthracis штаммов Ames, Stern 34F2 и JB17 позволило выявить в составе их хромосомной ДНК профаг, утративший часть структурных генов, необходимых для его репликации, но сохранивший ген, имеющий высокую степень гомологии с геном бактериолизина $\gamma$ фага. Последовательность данного гена, обозначенного как $P l y P H$, в базе данных NCBI представлена под номером NC_003997 [11].

Далее определили стратегию клонирования данного гена в E. coli. В качестве плазмиды для клонирования был выбран вектор pTrcHis2C размером 4,4 kb производства фирмы «Invitrogen» (США), схематически представленный на рисунке 1.

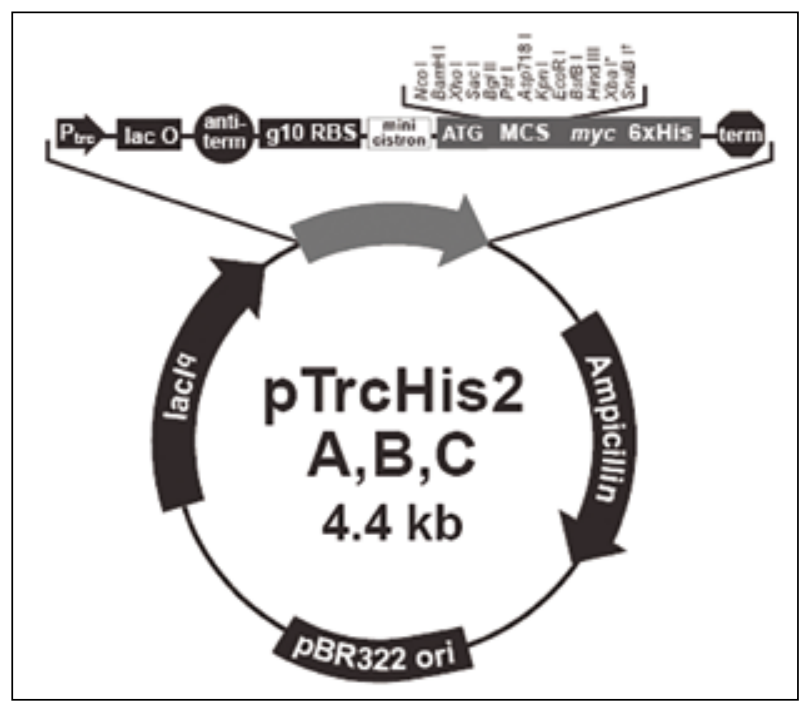

Рисунок 1 - Схематическое изображение вектоpapTrcHis2C

(Ptrc - изопропилтиогалактозид (ИПТГ) индуцируемый промотор по типу экспрессии лактозного оперона; LaCO - IaC-onepamop; MCS - полилинкер;

Ampicillin - ген устойчивости к ампициллину;

pBR322 оri - точка начала репликачии вектора из плазмиды pBR322 E. coli; laclq-ген, кодирующий белок-репрессор)

С учетом сайтов рестрикции полилинкера вектора pTrcHis2C, для амплификации и последующего клонирования гена $P l y P H$ нами были разработаны праймеры, содержащие сайты узнавания рестриктаз EcoRI и BamHI. Последовательности праймеров для амплификации и клонирования гена PlyPH B. anthracis и их основные свойства представлены в таблице 1.

Амплификацию гена $P l y P H$ в ПЦР с разработанной парой праймеров проводили методом ПЦР, используя в качестве матрицы ДНК штамма Stern 34F2 сибиреязвенного микроба. Температурно-временные режимы ПЦР подбирали экспериментально.

Результаты амплификации гена $\mathrm{PlyPH}$ при выборе оптимальной температуры гибриди-

Таблица 1 - Последовательности праймеров для амплификации и клонирования гена PlyPH B. anthracis и их основные свойства

\begin{tabular}{|c|c|c|c|c|}
\hline $\begin{array}{c}\text { Обозначение } \\
\text { праймера }\end{array}$ & $\begin{array}{l}\text { Нуклеотидная } \\
\text { последовательность } \\
\left(5^{\prime} \rightarrow 3^{\prime}\right)\end{array}$ & $\begin{array}{c}\text { Длина } \\
\text { праймера, н. }\end{array}$ & $\begin{array}{l}\text { Расчетная } \\
\text { температура } \\
\text { гибридизации, } \\
{ }^{\circ} \mathrm{C}\end{array}$ & $\begin{array}{l}\text { Размер } \\
\text { ожидаемого } \\
\text { амплификата, } \\
\text { п.н. }\end{array}$ \\
\hline PlyPH R & atgcgaattcttatttaacttcataccacc & 30 & 57,5 & \multirow{2}{*}{826} \\
\hline PlyPH L & atgggatccatgggttatattgtagatatttcg & 33 & 61,9 & \\
\hline \multicolumn{5}{|c|}{$\begin{array}{l}\text { Примечание. } \\
\text { Подчеркиванием выделены сайты узнавания рестриктаз EcoRI и BamHI для праймеров PlyPHR u PlyPHL } \\
\text { соответственно. }\end{array}$} \\
\hline
\end{tabular}




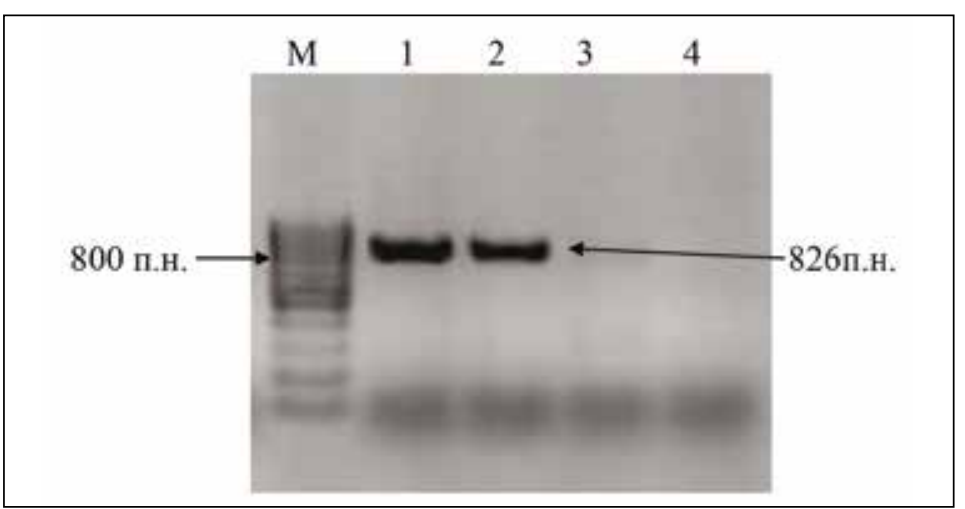

Рисунок 2 - Электрофореграмма продуктов амплификации гена РІуРН в 1,5\% агарозном геле

(М - маркер молекулярных масс ДНК 100 п.н.;

1-4 - продукты ПЦР гена РІуРН с разработанными праймерами при температуре гибридизачии $56,57,58$ и $59^{\circ} \mathrm{C}$ соответственно)

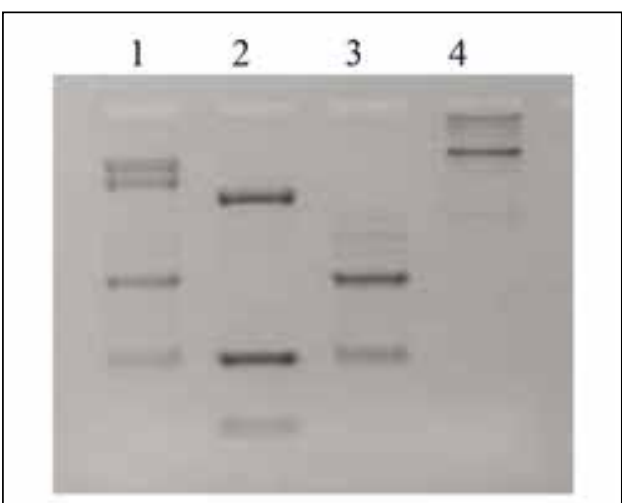

Рисунок 3 - Электрофореграмма результатов лигирования вектора pTrcHis2C и продукта амплификации гена PlyPH в 1,5\% агарозном геле (1 - смесь вектора и вставки после реакции лигирования; 2 - смесь вектора и вставки без лигазы; 3 - лигирование вставки «на себя»; 4-лигирование вектора «на себя») зации праймеров в ПЦР представлены на рисунке 2 .

Перед рестрикцией продукты амплификации очищали с помощью набора Montage PCR Centrifugal Filter Devices (фирмы «Millipore», США) в соответствие с рекомендациями производителя. Расщепление ДНК вектора и вставки проводили в одной реакционной смеси одновременно по двум сайтам рестрикции с помощью эндонуклеаз EcoRI и ВатН Н (НПО «СибЭнзим», Россия).

Для ковалентного сшивания полученных фрагментов по комплементарным («липким») концам использовали ДНК-лигазу фага Т4 (НПО «СибЭнзим», Россия). Лигирование ДНК вектора/вставки проводили при температуре $16{ }^{\circ} \mathrm{C}$ в течение 16-18 ч. Результаты лигирования вектора pTrcHis2C и амплификата гена PlyPH представлены на рисунке 3.

Эффективность лигирования оценивали методом электрофореза в 1,5\% агарозном геле по наличию дополнительных полос в смеси, содержащей ДНК вектора, вставки и лигазы фага T4 в соответствующем буфере в сравнении с контрольными препаратами ДНК.

Трансформацию клеток E. coli штамма TOР10 проводили по методу Т. Maniatis с соавт. с применением хлористого кальция [12]. Трансформационную смесь высевали на чашки Петри с плотной питательной средой (ППС), содержащей ампициллин в концентрации 100 мкг/ мл. Чашки инкубировали при температуре $(36 \pm 1)^{\circ} \mathrm{C}$ в течение 12-18 ч. Выросшие колонии трансформантов исследовали в ПЦР со специфическими праймерами на наличие вставки гена PlyPH. Всего было подтверждено ме- тодом ПЦР наличие гена $P l y P H$ у 18 клонов. Из данных колоний с помощью набора реактивов GeneJet $^{\mathrm{Tm}}$ Plasmid Miniprep Kit («Fermentas», Литва) выделяли плазмидную ДНК. Правильность встраивания гена $P l y P H$ подтверждали путем рестрикции ДНК отобранных клонов эндонуклеазами рестрикции EcoRI и BamHI. Для дальнейших исследований отбирали только те клоны, плазмидная ДНК которых расщеплялась указанными рестриктазами на фрагменты длиной около 4400 и 826 п.н. (ДНК вектора и вставки соответственно). Всего для дальнейшей работы было отобрано 3 рекомбинантных клона штамма TOP10 E. coli, несущих ген бактериолизина сибиреязвенного микроба.

Отобранные клоны культивировали в LB-бульоне с добавлением ампициллина до концентрации 100 мкг/мл в 250-мл колбах в течение 3 ч при 150 об/мин. После чего для индукции экспрессии рекомбинантного белка вводили синтетический аналог лактозы - ИПТГ до концентрации 1 мМ и продолжали культивирование в течение 2 ч при прежних условиях.

Белковый профиль рекомбинантных клонов анализировали методом электрофореза в ПААГ. Результаты белкового электрофореза отобранных клонов представлены на рисунке 4.

По результатам белкового электрофореза был отобран один клон, продуцирующий белок, по молекулярной массе соответствующий белку PlyPH - 32 кДа.

На следующем этапе было проведено исследование литических свойств продуцируемого рекомбинантным штаммом белка в отношении микробных клеток $B$. anthracis in vitro. Микробные клетки штамма TOP10 E. coli, несущие гибридную 
плазмиду pTrcHis2CPlyPH, культивировали в LB-бульоне с добавлением ампициллина до концентрации 100 мкг/мл в 250-мл колбах в течение 3 ч при (36 \pm 1$)^{\circ} \mathrm{C}$, после чего в объеме 0,1 мл высевали на чашки Петри с ППС, содержащей 100 мкг/ мл ампициллина и ИПТГ в концентрации $1 \mathrm{mM}$. Чашки инкубировали при температуре $(36 \pm 1){ }^{\circ} \mathrm{C}$ в течение 18 ч. По истечении указанного времени выросшие на ППС культуры лизировали хлороформом. Для чего по 5 мл хлороформа наливали в крышку каждой чашки Петри, после чего их закрывали и инкубировали при температуре $(36 \pm 1)^{\circ} \mathrm{C}$ в течение 5 мин. Лизированные культуры смывали 50 мМ раствором трис гидрохлорида (pH 8,0). Лизаты переносили в 1,5-мл микроцентрифужные пробирки и центрифугировали в течение 1 мин при 13 тыс. об/мин. Для дальнейших исследований использовали надосадочную жидкость.

Исследование литических свойств рекомбинантного фаголизина в отношении микробных клеток $B$. anthracis in vitro проводили с использованием вакцинного штамма СТИ-1 сибиреязвенного микроба. Для этого 0,1 мл ночной культуры штамма СТИ-1 с концентрацией $1 \times 10^{7} \mathrm{KOE} / \mathrm{мл} \mathrm{с} \mathrm{помощью} \mathrm{шпателя} \mathrm{после-}$ довательно распределяли на 3 чашки Петри по методу Дригальского, после чего на поверхность агара каждой чашки наносили в виде капли 0,05 мл лизата рекомбинантного штамма TOP10 E. coli с плазмидой pTrcHis2CPlyPH, 0,05 мл лизата штамма TOP10 E. coli с плазмидой pTrcHis2C без вставки и 0,05 мл суспензии рекомбинантного штамма TOP10 E. coli с плазмидой pTrcHis2CPlyPH, не подвергавшегося лизированию; четвертый сектор чашки служил контролем. Чашкам давали подсохнуть в течение 10 мин, переворачивали и инкубировали при температуре $(36 \pm 1){ }^{\circ} \mathrm{C}$ в течение 18-24 ч. Через указанное время проводили учет результатов. Результаты эксперимента представлены на рисунке 5.

Отсутствие специфического роста B. anthracis на ППС в месте нанесения клеточного лизата рекомбинантного штамма E. coli с клонированным геном $P l y P H$ в сравнении с контролем (наличие роста во всех остальных случаях) свидетельствовали о литической активности рекомбинантного белка в отношении вегетативных клеток штамма СТИ-1 сибиреязвенного микроба.

Таким образом, в ходе проведенных исследований был сконструирован рекомбинантный штамм E. coli, продуцирующий бактериолизин сибиреязвенного профага $\mathrm{PlyPH}$, который обладает способностью in vitro лизировать вегетативные клетки B. anthracis.

В дальнейших исследованиях по данному направлению целесообразно изучить спектр литической активности фаголизина в

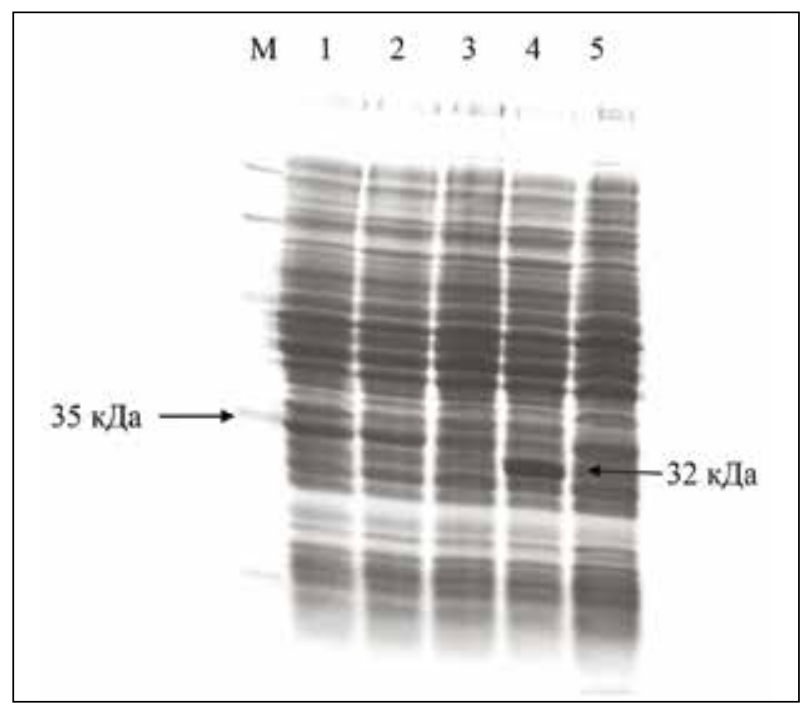

Рисунок 4 - Белковый профиль культуральных лизатов реципиентных и рекомбинантных штаммов

(М - маркер молекулярных масс белков 20-120 кДа; 1 - бесплазмидный реципиентный штамм TOP10 E. coli; 2 - штамм TOP10 E. coli, несущий вектор pTrcHis2C без вставки; 3, 4, 5 - рекомбинантные клоны штамма TOP10 E. coli, несущие гибридную плазмиду рTrcHis2(PlyPH)

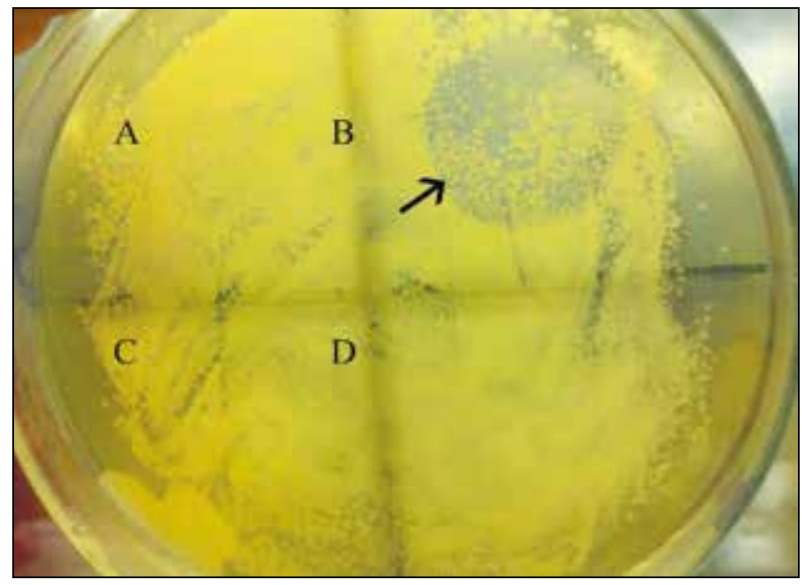

Рисунок 5 - Исследование литических свойств рекомбинантного фаголизина PlyPH in vitro в отношении микробных клеток штамма СТИ-1 B. anthracis

(A - область нанесения лизата штамма ТОР10 E. coli с плазмидой pTrcHis2C без вставки; B - область нанесения лизата рекомбинантного uтамма TOP10 E. coli с плазмидой pTrcHis2CPlyPH;

C - область нанесения суспензии рекомби-

нантного штамма TOP10 E. coli с плазмидой pTrcHis2CPlyPH, не подвергавшегося лизированию; D - контроль; стрелкой указана зона лизиса клеток штамма СТИ-1 B. anthracis)

отношении различных штаммов B. anthracis и близкородственных бацилл, в том числе и 
атипичных, получить очищенный препарат и оценить возможность его использования в качестве диагностического средства или специ- фического препарата для профилактики и лечения экспериментальной сибиреязвенной инфекции.

\section{Информация о конфликте интересов}

Авторы заявляют, что исследования проводились при отсутствии любых коммерческих или финансовых отношений, которые могли бы быть истолкованы как потенциальный конфликт интересов.

\section{Сведения о рецензировании}

Статья прошла открытое рецензирование двумя рецензентами, специалистами в данной области. Рецензии находятся в редакции журнала.

\section{Список источников}

1. Бургасов П.Н., Черкасский Б.Л., Марчук Л.М. и др. Сибирская язва. М.: Медицина, 1970.

2. Онищенко Г.Г., Васильев Н.Т., Литусов Н.В. и др. Сибирская язва: актуальные аспекты микробиологии, эпидемиологии, клиники, диагностики, лечения и профилактики. М.: ВУНМЦ МЗ РФ, 1999.

3. Онищенко Г.Г. Инфекционные болезни - важнейший фактор биоопасности // Эпидемиология и инфекционные болезни. 2003. № 3. С. 4-16.

4. Онищенко Г.Г., Федоров Ю.М., Тихонов Н.Г. и др. Противодействие биотерроризму как новая проблема эпидемиологии // Эпидемиология и инфекционные болезни. 2003. № 2. С. 4-6.

5. Inglesby T.V., Henderson D., Bartlett J.G. et al. Anthrax as a biological weapon. Updated recommendations for management // JAMA. 2002. V. 287. P. 2236-2252.

6. Pile J.C., Malone J.D., Eitzen E.M. et al. Anthrax as a potential biological warfare agent // Arch. Int. Med. 1998. V. 158. P. 429-434.
7. Young R. Bacteriophage lysis: mechanism and regulation // Microbiol. Rev. 1992. V. 56, № 3. P. 430-481.

8. Cheng Q., Nelson D., ZhuS. et al. Removal of group $B$ streptococci colonizing the vagina and oropharynx of mice with a bacteriophage lytic enzyme // Antimicrobial Agents Chemotherapy. 2005. V. 49, № 1. P. 111-117.

9. Jado I., Lopez R., Garcia E. et al. Phage lytic enzymes as therapy for antibiotic-resistant Streptococcus pneumoniae infection in a murine sepsis model // Antimicrobial Agents Chemotherapy. 2003. V. 52, № 6. P. 967-973.

10. Schuch R., Nelson D., Fischetti V.A. A bacteriolytic agent that detects and kills Bacillus anthracis // Nature. 2002. V. 418, № 22. P. 884-888.

11. Yoong P., Schuch R., Nelson D. et al. PlyPH, a bacteriolytic enzyme with a broad $\mathrm{pH}$ range of activity and lytic action against Bacillus anthracis // J. Bacteriol. 2006. V. 188, № 7. P. 2711-2714.

12. Маниатис Т., Фрич Э., Самбрук Дж. Молекулярное клонирование: пер. с англ. М.: Мир, 1984.

\section{Об авторах}

Филиал федерального государственного бюджетного учреждения «48 Центральный научно-исследовательский институт» Министерства обороны Российской Федерации. 610000, Российская Федерация, г. Киров, Октябрьский проспект, д. 119

Онучина Наталья Викторовна. Младший научный сотрудник научно-исследовательского отдела, канд. биол. наук.

Кузнецовский Андрей Владимирович. Начальник отдела планирования научно-исследовательских работ - заместитель начальника научно-исследовательского центра по научно-исследовательской работе, канд. биол. наук.

Сойбанов Владимир Дмитриевич. Младший научный сотрудник научно-исследовательского отдела.

Контактная информация для всех авторов: 23527@mil.ru Контактное лицо: Онучина Наталья Викторовна; 23527@mil.ru 


\title{
The Production of the Recombinant Protein of Anthrax Bacteriolysine PlyPH and In Vitro Study of the Lytic Properties of the Protein Coded for them Against Bacillus anhracis Microbial Cells
}

\author{
N.V. Onuchina, A.V. Kuznetsovskiy, V.D. Soybanov \\ Branch Office of the Federal State Budgetary Establishment "48 Central Scientific Research \\ Institute» of the Ministry of Defense of the Russian Federation, \\ Oktyabrsky Avenue 119, Kirov 610000, Russian Federation
}

\begin{abstract}
The causative agent of anthrax - Bacillus anthracis, due to the prevalence of its natural foci in Russia, high virulence for humans and most mammals, the unique resistance of spore forms to environmental factors and repeated use in terrorist acts, is an extremely dangerous biological agent. Therefore, the search for new effective drugs for the diagnosis and treatment of anthrax, including diseases caused by antibiotic-resistant strains of $B$. anthracis is necessary. The use of lytic enzymes of species-specific bacteriophages is a new trend in the diagnosis, prevention and treatment of infectious diseases. The goal of this work is the cloning of the anthrax bacteriolysin $\mathrm{PlyPH}$ gene as part of the $\mathrm{pTrcHis} 2 \mathrm{C}$ vector in Escherichia coli and the in vitro study of the lytic properties of the protein encoded by it against B. anthracis microbial cells. According to the complete sequencing of the B. anthracis genomes of the Ames, Stern 34F2 and JB17 strains, a prophage was found in their chromosomal DNA, which lost part of the structural genes necessary for its replication, but retained a gene with a high degree of homology with the bacteriolysin $\gamma$ phage gene. For amplification and subsequent cloning of the PlyPH gene, we developed primers containing EcoRI and BamHI restriction enzyme recognition sites. Amplification of the $\mathrm{Ply} P H$ gene in a polymerase chain reaction (PCR) with a developed pair of primers was performed using the Stern 34F2 strain of the anthrax microbe as a template. Based on the obtained amplification products and the $\mathrm{pTrcHis} 2 \mathrm{C}$ vector, we constructed a recombinant plasmid containing the bacteriolysin synthesis $\mathrm{PlyPH}$ gene and stably functioning in the cells of the recombinant $E$. coli strain. In the course of research, it has been established that microbial cells of the E. coli recombinant TOP10 strain provide for the production of the bacteriolysin of the anthrax prophage, $P l y P H$, which has the ability to in vitro lyse the vegetative cells of the STI-1 vaccine strain of $B$. anthracis.
\end{abstract}

Keywords: Bacillus anthracis; vector pTrcHis2C; cloning; anthrax bacteriolysin $\mathrm{Ply} P H$, anthrax prophage, anthrax.

For citation: Onuchina N.V., Kuznetsovskiy A.V., Soybanov V.D. The Production of the Recombinant Protein of Anthrax Bacteriolysine PlyPH and In Vitro Study of the Lytic Properties of the Protein Coded for them Against Bacillus anhracis Microbial Cells // Journal of NBC Protection Corps. 2019. V. 3. № 1. P. 15-22.

Conflict of interest statement

The authors declare that the research was conducted in the absence of any commercial or financial relationship that could be construed as a potential conflict of interest.

Peer review information

The article has been peer reviewed by two experts in the respective field. Peer reviews are available from the Editorial Board. 


\section{References}

1. Burgasov P.N., Cherkasskii B.L., Marchuk L.M. et al. Sibirskaia iazva [Anthrax]. Moscow: Medicine Publ., 1970 (in Russian).

2. Onishchenko G.G., Vasil'ev N.T., Litusov N.V. et al. Sibirskaia iazva: aktual'nye aspekty mikrobiologii, epidemiologii, kliniki, diagnostiki, lecheniia i profilaktiki [Anthrax: Actual Aspects of Microbiology, Epidemiology, Clinic, Diagnosis, Treatment and Prevention]. Moscow: VUNMTs MZ RF Publ., 1999 (in Russian).

3. Onishchenko G.G. Infectious diseases - the most important factor of biohazard. Epidemologiia i infektsionnye bolezni [Epid. Infect. Diseases], 2003. no. 3. P. 4-16 (in Russian).

4. Onishchenko G.G., Fedorov Iu.M., Tikhonov N.G. et al. Counteracting bioterrorism as a new problem in epidemiology. Epidemiologiia i infektsionnye bolezni [Epid. Infect. Diseases], 2003, no. 2, P. 4-6 (in Russian).

5. Inglesby T.V., Henderson D., Bartlett J.G. et al. Anthrax as a biological weapon. Updated recommendations for management // JAMA. 2002. V. 287. P. 2236-2252.

6. Pile J.C., Malone J.D., Eitzen E.M. et al. Anthrax as a potential biological warfare agent // Arch. int. Med. 1998. V. 158. P.429-434.

7. Young R. Bacteriophage lysis: mechanism and regulation // Microbiol. Rev. 1992. V. 56, No. 3. P. 430-481.

8. Cheng Q., Nelson D., Zhu S. et al. Removal of group $B$ streptococci colonizing the vagina and oropharynx of mice with a bacteriophage lytic enzyme // Antimicrobial Agents and Chemotherapy. 2005. V. 49, No. 1. P. 111-117.

9. Jado I., Lopez R., Garcia E. et al. Phage lytic enzymes as therapy for antibiotic-resistant Streptococcus pneumoniae infection in a murine sepsis model // Antimicrobial Agents Chemotherapy. 2003. V. 52, No. 6. P. 967-973.

10. Schuch R., Nelson D., Fischetti V.A. A bacteriolytic agent that detects and kills Bacillus anthracis // Nature. 2002. V. 418, No. 22. P. 884-888.

11. Yoong P., SchuchR., Nelson D., et al. PlyPH, a Bacteriolytic enzyme with a broad $\mathrm{pH}$ range of activity and lytic action against Bacillus anthracis // J. Bacteriol. 2006. V. 188, No. 7. P. 2711-2714.

12. Maniatis T., Frich E., Sambruk Dzh. Molecular Cloning. Transl. from Eng. Moscow: Mir Publ., 1984 (in Russian).

\section{Authors}

Branch Office of the Federal State Budgetary Establishment «48 Central Scientific Research Institute» of the Ministry of Defense of the Russian Federation, Oktyabrsky Avenue 119, Kirov 610000, Russian Federation

Natalia Victorovna Onuchina. Junior Researcher of Scientific and Research Department. Candidate of Biological Sciences.

Andrey Vladimirovich Kuznetsovskiy. Chief of the Department of Planning Research Projects -Deputy Chief of the Scientific and Research Center for Scientific Research. Candidate of Biological Sciences.

Vladimir Dmitrievich Soybanov. Junior Researcher of Scientific and Research Department.

Contact information for all authors:23527@mil.ru Contact person: Onuchina Natalia Viktorovna; 23527@mil.ru 